\title{
Type of corn endosperm influences nutrient digestibility in lactating dairy cows
}

\author{
J. C. Lopes, ${ }^{*}$ R. D. Shaver, ${ }^{1}{ }^{1}$ P. C. Hoffman, ${ }^{*}$ M. S. Akins, ${ }^{*}$ S. J. Bertics, ${ }^{*}$ H. Gencoglu, $†$ and J. G. Coors $\ddagger$ \\ ${ }^{*}$ Department of Dairy Science, University of Wisconsin-Madison, 1675 Observatory Dr., Madison 53706 \\ †Department of Animal Nutrition and Nutritional Diseases, Faculty of Veterinary Medicine, University of Uludag, Bursa, 16059, Turkey \\ ‡Department of Agronomy, University of Wisconsin-Madison, 1675 Observatory Dr., Madison 53706
}

\section{ABSTRACT}

An experiment was conducted to evaluate the effect of type of corn endosperm on nutrient digestibility in lactating dairy cows. Near-isogenic variants of an Oh43 $\times$ W64A normal dent endosperm hybrid carrying floury-2 or opaque-2 alleles were grown in spatial isolation in field plots and harvested as dry shelled corn. Six ruminally cannulated, multiparous Holstein cows $(67 \pm 9 \mathrm{~d}$ in milk at trial initiation) were randomly assigned to a replicated $3 \times 3$ Latin square design with 14 -d periods; the first $11 \mathrm{~d}$ of each period were for diet adaptation followed by $3 \mathrm{~d}$ of sampling and data collection. Treatment diets that contained dry rolled vitreous-, floury-, or opaque-endosperm corn [33\% of dry matter (DM)], alfalfa silage (55\% of DM) and protein-mineral-vitamin supplement $(12 \%$ of DM) were fed as a total mixed ration. The percentage vitreous endosperm was zero for floury and opaque endosperm corns and $64 \pm 7 \%$ for the vitreous corn. Prolamin protein content of floury and opaque endosperm corns was $30 \%$ of the content found in vitreous corn. Degree of starch access and in vitro ruminal starch digestibility measurements were 32 and $42 \%$ greater on average, respectively, for floury and opaque endosperm corns than for vitreous corn. Dry matter and starch disappearances after 8-h ruminal in situ incubations were, on average, 24 and 32 percentage units greater, respectively, for floury and opaque endosperm corns than for vitreous corn. Ruminal $\mathrm{pH}$ and acetate molar percentage were lower, propionate molar percentage was greater, and acetate:propionate ratio was lower for cows fed diets containing floury and opaque endosperm corns than for cows fed vitreous corn. In agreement with laboratory and in situ measurements, total-tract starch digestibility was 6.3 percentage units greater, on average, for cows fed diets containing floury and opaque endosperm corns than vitreous corn. Conversely, apparent total-tract neutral

Received January 30, 2009.

Accepted May 2, 2009.

${ }^{1}$ Corresponding author: rdshaver@wisc.edu detergent fiber (NDF) digestibility was lower for cows fed diets containing floury and opaque endosperm corns compared with vitreous corn. The type of endosperm in corn fed to dairy cows can have a marked effect on digestion of starch and NDF. Feeding less vitreous corn increased starch digestion but decreased NDF digestion.

Key words: corn, digestibility, lactating cow, starch

\section{INTRODUCTION}

Starch in corn grain is a major source of energy in dairy cattle diets. Total-tract digestibility of corn starch by dairy cows was highly variable $(\mathrm{n}=83$, mean $=90.6 \%, \mathrm{SD}=7.4 \%$, and range $=30 \%)$ among experiments in the literature review of Firkins et al. (2001). Accounting for this variation were conservation method (high-moisture $>$ dry corn), processing method (ground $>$ rolled corn; steam flaked $>$ steam rolled $>$ dry rolled corn), and particle size (fine ground $>$ rolled or cracked dry corn).

Kernel vitreousness, the ratio of vitreous to floury endosperm, has been used to assess the type of corn endosperm (Ngonyamo-Majee et al., 2008a,b). Increased kernel vitreousness reduced ruminal in situ corn starch degradation (Philippeau and Michalet-Doreau, 1997; Correa et al., 2002; Ngonyamo-Majee et al., 2008b). Kernel vitreousness was lower and ruminal in situ starch degradation was greater for dry corn with floury or opaque endosperm than with normal dent endosperm (Ngonyamo-Majee et al., 2008a,b). Taylor and Allen (2005a) reported greater ruminal and total-tract starch digestibilities in ruminally and duodenally cannulated lactating dairy cows for floury (3\% vitreousness) versus normal dent (67\% vitreousness) endosperm dry corn.

Our objective was to use near-isogenic variants of corn hybrid Oh43 $\times$ W64A carrying floury-2 and opaque-2 alleles found to reduce vitreousness and increase ruminal in situ starch degradation (NgonyamoMajee et al., 2008a,b) to evaluate the effect of type of corn endosperm on nutrient digestibility in lactating dairy cows. 
Table 1. Ingredient and nutrient composition of the diets

\begin{tabular}{|c|c|c|c|}
\hline Item & & $\mathrm{TMR}^{1}$ & \\
\hline $\begin{array}{l}\text { Ingredient, } \% \text { of DM } \\
\text { Alfalfa silage }{ }^{2} \\
\text { Rolled shelled corn } \\
\text { Soybean meal- } 48 \% \\
\text { Tallow } \\
\text { Calcium carbonate } \\
\text { Sodium bicarbonate } \\
\text { Magnesium oxide } \\
\text { Mg-K-S }{ }^{3} \\
\text { Sodium chloride } \\
\text { Trace mineral salt } \\
\text { Vitamin premix } \\
\text { Selenium } 0.02 \%\end{array}$ & ISO & $\begin{array}{l}55.0 \\
33.0 \\
9.6 \\
0.48 \\
0.50 \\
0.53 \\
0.13 \\
0.05 \\
0.17 \\
0.33 \\
0.17 \\
0.04 \\
\text { FL }\end{array}$ & $\mathrm{OP}$ \\
\hline $\begin{array}{l}\text { Nutrient }^{6,7} \text { (DM basis) } \\
\text { OM, \% } \\
\text { CP, \% } \\
\text { NDF, \% } \\
\text { Starch, \% }\end{array}$ & $\begin{array}{l}86.3 \pm 0.8 \\
19.7 \pm 0.2 \\
31.0 \pm 3.9 \\
20.8 \pm 1.2\end{array}$ & $\begin{array}{l}86.3 \pm 0.7 \\
19.7 \pm 0.9 \\
29.8 \pm 2.3 \\
18.5 \pm 0.4\end{array}$ & $\begin{array}{l}86.8 \pm 1.2 \\
19.5 \pm 0.7 \\
29.9 \pm 3.2 \\
18.9 \pm 1.1\end{array}$ \\
\hline
\end{tabular}

${ }^{1}$ Treatments were dry rolled shelled corn from either $\mathrm{W} 64 \mathrm{~A} \times \mathrm{OH} 43$ $(\mathrm{ISO}), \mathrm{W} 64 \mathrm{~A} \times \mathrm{OH} 43 \mathrm{fl} / \mathrm{fl} 2(\mathrm{FL})$, or $\mathrm{W} 64 \mathrm{~A} \times \mathrm{OH} 43$ o2/o2 $(\mathrm{OP})$ varieties fed in TMR.

${ }^{2} \mathrm{DM}=42.7 \pm 3.2 \% ; \mathrm{CP}=19.2 \pm 2.9 \% ; \mathrm{NDF}=46.0 \pm 5.5 \%$.

${ }^{3}$ Dynamate $(11 \% \mathrm{Mg}, 18 \% \mathrm{~K}, 22 \% \mathrm{~S}$; The Mosaic Co., Plymouth, $\mathrm{MN})$.

${ }^{4} 88 \% \mathrm{NaCl} ; 0.002 \% \mathrm{Co} ; 0.2 \% \mathrm{Cu} ; 0.012 \%$ I; $0.18 \% \mathrm{Fe} ; 0.8 \% \mathrm{Mn}$; $0.006 \%$ Se; $1.4 \% \mathrm{Zn}$.

${ }^{5}$ Vitamin A 3,300,000 IU/kg; vitamin D 1,100,000 IU/kg; vitamin E $11,000 \mathrm{IU} / \mathrm{kg}$.

${ }^{6}$ Orts-adjusted diet nutrient composition.

${ }^{7} \mathrm{DM}$ content of TMR $46.7 \% \pm 5.6$.

\section{MATERIALS AND METHODS}

The experimental corn hybrid varieties were $\mathrm{W} 64 \mathrm{~A} \times$ $\mathrm{OH} 43(\mathbf{I S O}), \mathrm{W} 64 \mathrm{~A} \times \mathrm{OH} 43 \mathrm{fl} / \mathrm{fl} 2(\mathbf{F L})$, and W64A $\times$ OH43 o2/o2 $(\mathbf{O P})$. All varieties were planted in 0.75 ha plots at University of Wisconsin Arlington Research Station (Arlington, WI) at a density of 59,000 plants/ ha. The FL and OP plots were planted in 1-km spatial isolation of the ISO plot to prevent cross-pollination to preserve endosperm properties associated with the recessive alleles. Each field plot was combine harvested as shelled corn after field drying to approximately $20 \%$ moisture, and then each lot of corn was air-dried at low temperature $\left(<32^{\circ} \mathrm{C}\right)$ in storage bins to approximately $14 \%$ moisture at Wisconsin Foundation Seeds (Arlington, WI). Percentage vitreous endosperm, determined as described by Correa et al. (2002), was zero for both FL and OP kernels and $64 \pm 7 \%$ for ISO kernels. Before the feeding trial was conducted, each lot of corn was processed using a stationary roller mill (A. O. Smith Corp., Milwaukee, WI) with the roll clearance set at 1 mm and bagged.

Six ruminally cannulated, multiparous Holstein cows $(638 \pm 5 \mathrm{~kg}$ of $\mathrm{BW}$ and $67 \pm 9$ DIM at trial initiation) were randomly assigned to a replicated $3 \times 3$ Latin square design with 14-d periods; the first $11 \mathrm{~d}$ of each period were for diet adaptation followed by $3 \mathrm{~d}$ for sampling and data collection. All experimental procedures were approved by the Research Animal and Resource Center of the College of Agriculture and Life Sciences, University of Wisconsin-Madison. Experimental diets contained ISO, FL, or OP dry rolled corn (33\% of diet $\mathrm{DM}$ ) and alfalfa silage (55\% of diet DM) along with soybean meal, tallow, and mineral-vitamin ingredients. With these ingredient constraints set, diets were formulated to meet or exceed NRC (2001) CP and macromineral concentration guidelines for early lactation cows. Trace minerals and vitamins were supplemented to meet or exceed NRC (2001) guidelines. Ingredient and nutrient composition of the experimental diets are presented in Table 1. Diets were formulated to contain 18.5\% CP (DM basis) so that RDP was not limiting for ruminal digestion. The orts-adjusted diets contained 19.5 to $19.7 \%$ CP (DM basis), however, because the alfalfa silage and soybean meal fed during the trial were both higher in CP than the values used for the pretrial formulations.

Cows were housed in tie-stalls and milked twice daily in a parlor with yield recorded at each milking for each cow. Milk samples were collected from each cow at each milking on the last $3 \mathrm{~d}$ of each period and analyzed for fat, true protein, lactose, and MUN concentrations using infrared analysis (AgSource Milk Analysis Laboratory, Menomonie, WI). Cows were fed individually a TMR at 6 -h intervals daily for $5 \%$ refusals with the amounts fed and refused recorded once daily. The alfalfa silage DM content was determined weekly with the as-fed proportions of alfalfa silage, respective treatment corns, and the protein-mineral-vitamin concentrate adjusted as necessary to maintain the desired DM proportions of these ingredients in the TMR.

The treatment corns and TMR sampled daily during each sampling period and alfalfa silage and concentrate sampled weekly throughout the trial were dried at $60^{\circ} \mathrm{C}$ for $48 \mathrm{~h}$ in a forced-air oven to determine DM content, ground to pass a 1-mm Wiley mill (Arthur H. Thomas, Philadelphia, PA) screen, and composited by period for the following analyses at a commercial feed testing laboratory (Dairyland Laboratories Inc., Arcadia, $\mathrm{WI}$ ): $\mathrm{OM}$ (ashing at $600^{\circ} \mathrm{C}$ for $2 \mathrm{~h}$ ), $\mathrm{CP}$ (AOAC, 1995), NDF using $\alpha$-amylase and sodium sulfite (Van Soest et al., 1991), and starch (Ehrman, 1996; YSI Biochemistry Analyzer, YSI Inc., Yellow Springs, OH). Separate samples of the treatment corns were composited by period, left undried and unground, and sent to commercial feed testing laboratories for analyses as follows: mean particle size (MPS) determined at Dairyland Laboratories Inc. (Arcadia, WI) by dry sieving using a 
Tyler Ro-Tap Shaker Model RX-29 (Mentor, $\mathrm{OH}$ ) and sieves with apertures of $2,360,1,700,1,180,850,600$, $425,300,212,150,106,75$, and $53 \mu \mathrm{m}$ plus bottom pan, and calculated using a log normal distribution (Waldo et al., 1971); degree of starch access (Blasel et al., 2006) and prolamin protein (Larson and Hoffman, 2008) determined at the University of Wisconsin-Madison Soil and Plant Analysis Laboratory (Marshfield, WI); 7-h in vitro ruminal starch digestibility determined at Cumberland Valley Analytical Services Inc. (Maugansville, MD). The Cumberland Valley Analytical Services in vitro ruminal starch digestibility procedure was as follows: corn grain ground to pass a $2-\mathrm{mm}$ screen in a Udy Cyclone Mill (Udy Corp., Fort Collins, CO); 1.0-g samples weighed into $125-\mathrm{mL}$ Erlenmeyer flasks, reducing $(2 \mathrm{~mL})$ and buffer $(40 \mathrm{~mL})$ solutions added to the flasks, and $\mathrm{O}_{2}$ purged from the flasks with $\mathrm{CO}_{2}$; rumen fluid from 3 mid-lactation, ruminally cannulated dairy cows fed a corn silage-alfalfa silage based TMR combined, strained through nylon mesh, and $20 \mathrm{~mL}$ added to each flask; flasks maintained in a $40^{\circ} \mathrm{C}$ water bath under $\mathrm{CO}_{2}$ for $7 \mathrm{~h}$ and then removed from the water bath and refrigerated overnight; residue remaining in the flasks analyzed for starch using thermo-stable amylase incubation followed by glucose analysis with an Astoria auto-analyzer (Astoria-Pacific Int., Clackamas, OR).

Fecal grab samples were collected from each cow twice daily to cover 0400, 0800, 1200, 1600, 2000, and $2400 \mathrm{~h}$ time points over the 3 -d sampling period. Ort samples were collected from each cow daily during the 3 -d sampling period. Fecal and ort samples were dried and ground as described previously and composited by cow within period; composite samples were analyzed for DM, OM, CP, NDF, and starch as described previously.

Ruminal fluid was collected from each cow immediately before the $0600 \mathrm{~h}$ feeding and at 2, 4, 8, and 16 $\mathrm{h}$ after that feeding on the first $2 \mathrm{~d}$ of each sampling period. Samples were collected from 5 sites within the ventral rumen via the cannula using a metal filter probe. The fluid was immediately filtered through 2 layers of cheesecloth, and $\mathrm{pH}$ was measured (Cardy Twin pH meter Model 2103-A, Spectrum Technologies Inc., Plainfield, IL). Duplicate 1-mL strained rumen fluid samples were acidified in $20 \mu \mathrm{L}$ of $50 \% \mathrm{H}_{2} \mathrm{SO}_{4}$ solution, and immediately frozen in microfuge tubes until VFA analysis. After thawing, the rumen fluid was centrifuged at $10,000 \times g$ for $3 \mathrm{~min}$. Then, $0.6 \mathrm{~mL}$ of supernatant was added to $0.12 \mathrm{~mL}$ of $25 \%$ metaphosphoric acid and allowed to stand at room temperature for $30 \mathrm{~min}$. The sample was centrifuged again at 10,000 $\times g$ for $3 \mathrm{~min}$. The supernatant was transferred to a gas-liquid chromatography vial for analysis on a Perkin
Elmer Autosystem gas chromatograph (Perkin Elmer Instruments, Shelton, CT) using a 1.8-m column (Supelco, Bellefonte, PA) packed with 4\% Carbowax 20M 80/120 Carbopack B-DA with an oven temperature of $160^{\circ} \mathrm{C}$ and a nitrogen flow rate of $24 \mathrm{~mL} / \mathrm{min}$. Separate duplicate 1-mL strained rumen fluid samples were acidified in $20 \mu \mathrm{L}$ of $50 \%$ TCA solution and immediately frozen in microfuge tubes until prepared and analyzed for ammonia-N as described by (Bal et al., 2000).

Dacron bags $(10 \times 15 \mathrm{~cm}, 52 \pm 5 \mu \mathrm{m}$ pore size, R102 Marvelaire White, Balson Erlanger, New York, NY) containing approximately $5 \mathrm{~g}$ (as-fed basis and not reground) of the same treatment corn being fed to the incubation cow were inserted via the cannula in weighted nylon-mesh laundry bags positioned in the ventral rumen at the $0600 \mathrm{~h}$ feeding and at $1400 \mathrm{~h}$ for 16 - and 8-h incubations, respectively (all bags were removed at $2200 \mathrm{~h}$ ), on the last day of each sampling period to determine ruminal DM and starch disappearance for the treatment corns. Triplicate bags were used for each treatment at each incubation time. Immediately upon removal from the rumen, bags were immersed in ice water until washing. Zero-hour bags were not inserted ruminally, but were soaked in tepid tap water for 30 min. All bags were washed using cold water for 2 cycles in a commercial washing machine (Cherney et al., 1990), dried at $60^{\circ} \mathrm{C}$ for $72 \mathrm{~h}$, and weighed to determine the amount of DM remaining in the bags for calculation of ruminal DM disappearance percentages. Triplicate bag residues were then composited, ground, and analyzed for starch content as described previously to determine the amount of starch remaining in bags for calculation of ruminal starch disappearance percentages.

Total-tract nutrient digestibilities were determined using 120-h indigestible NDF as an internal marker. Following completion of the Latin square, the 6 cows remained on a TMR consisting of the same DM proportions of alfalfa silage, protein-mineral-vitamin concentrate, and a corn mixture composed equally of the 3 treatment corns for $2 \mathrm{wk}$. Composite fecal, ort, and TMR samples were incubated ruminally in Dacron bags in triplicate for 120-h during the last $5 \mathrm{~d}$ of the 2 -wk feeding period. In situ Dacron bag procedures were as described previously. The NDF content of the bag residues was determined in triplicate using $\alpha$-amylase and sodium sulfite (Van Soest et al., 1991) and an Ankom ${ }^{200}$ Fiber Analyzer (Ankom Technology, Fairport, NY). Total-tract nutrient digestibilities were calculated from 120-h indigestible NDF and nutrient concentrations in the orts-adjusted diet and feces.

Data were analyzed as a replicated Latin square using the PROC MIXED procedure (SAS Institute, 2004). The model included square, period, and treatment as fixed effects; cow within square was a random effect. 
LOPES ET AL.

Table 2. Laboratory evaluation of the experimental corn varieties ${ }^{1}$

\begin{tabular}{|c|c|c|c|}
\hline Item & ISO & FL & $\mathrm{OP}$ \\
\hline DM, \% as fed & $87.4 \pm 0.2$ & $86.9 \pm 0.3$ & $86.0 \pm 0.3$ \\
\hline $\mathrm{CP}, \%$ of $\mathrm{DM}$ & $10.4 \pm 0.1$ & $10.8 \pm 0.2$ & $10.2 \pm 0.2$ \\
\hline Starch, \% of DM & $69.2 \pm 0.4$ & $62.9 \pm 0.7$ & $67.5 \pm 1.5$ \\
\hline Mean particle size, $\mu \mathrm{m}$ & $1,792 \pm 125$ & $1,394 \pm 116$ & $1,456 \pm 160$ \\
\hline Vitreousness, \% & $64 \pm 7$ & 0 & 0 \\
\hline \multicolumn{4}{|l|}{ Prolamin protein } \\
\hline$\%$ of DM & $7.50 \pm 0.52$ & $2.80 \pm 0.17$ & $1.73 \pm 0.06$ \\
\hline$\%$ of $\mathrm{CP}$ & $72.2 \pm 6.0$ & $26.2 \pm 1.9$ & $17.4 \pm 0.7$ \\
\hline$\%$ of starch & $10.8 \pm 0.8$ & $4.5 \pm 0.3$ & $2.6 \pm 0.1$ \\
\hline \multicolumn{4}{|l|}{ Degree of starch access ${ }^{2}$} \\
\hline$\%$ starch & $53.5 \pm 1.5$ & $69.4 \pm 1.3$ & $71.5 \pm 1.8$ \\
\hline \multicolumn{4}{|l|}{ In vitro ruminal starch digestibility ${ }^{3}$} \\
\hline 7-h, \% starch & $62 \pm 2$ & $91 \pm 2$ & $85 \pm 4$ \\
\hline
\end{tabular}

Ruminal data were analyzed with time as repeated measures using the first-order autoregressive covariance structure that provided the best fit according to Sawa's Bayesian information criterion. Degrees of freedom were calculated using the Kenward-Roger option. Preplanned contrasts were included to compare ISO versus FL and OP, and FL versus OP. The least squares mean statement was used to determine treatment means. Statistical significance and trends were considered at $P$ $\leq 0.05$ and $P \geq 0.06$ to $P<0.10$, respectively.

\section{RESULTS AND DISCUSSION}

Results of analysis of the experimental corn hybrid varieties are presented in Table 2. The treatment corns were of similar DM and $\mathrm{CP}$ content. The FL corn contained approximately 6 percentage units less starch than ISO. The starch content for OP was more variable than for ISO (SD 1.5 vs. $0.4 \%$ ).

Despite similar mechanical processing of the treatment corns, MPS was lower for FL and OP corns compared with ISO. Taylor and Allen (2005a) reported that MPS was lower for floury compared with vitreous corn $(1,377$ vs. $1,594 \mu \mathrm{m})$ fed in their trial despite similar mechanical processing for both types of corn. The magnitude of the endosperm effect on processed dry corn MPS was similar for both experiments; $20 \%$ lower MPS on average for FL and OP than ISO in our trial and $14 \%$ lower MPS for floury compared with vitreous corn in the trial of Taylor and Allen (2005a). Reduced MPS of dry corn has been shown to increase total-tract digestibility of starch by dairy cows (Knowlton et al., 1998), but with greater reductions in MPS (64 vs. 14 and $20 \%)$ and at lower MPS $(618 \mu \mathrm{m}$ vs. 1,377 and $1,394 \mu \mathrm{m})$ when comparing MPS for that trial to MPS from our trial and the trial of Taylor and Allen (2005a).
Allen et al. (2008) evaluated floury versus vitreous dry corn and fine versus medium particle size in a factorial experiment; total-tract digestibility of starch by dairy cows was greater for floury than for vitreous corn but was unaffected by fineness of grind. From the foregoing discussion, we suggest that differences in MPS between the experimental corns in our study had much less effect on the results than did differences in kernel vitreousness or prolamin protein content.

Percentage vitreous endosperm was zero for both FL and OP kernels and $64 \pm 7 \%$ for ISO kernels. Taylor and Allen (2005a) reported greater ruminal and totaltract starch digestibilities in lactating dairy cows for floury (3\% vitreousness) versus normal dent (67\% vitreousness) endosperm dry corn. Prolamin protein concentrations, expressed as percentages of DM, CP, and starch, for FL and OP, on average, were reduced by $70 \%$ relative to the concentrations found for ISO. Highly vitreous corn types contain higher concentrations of prolamin proteins than floury or opaque corn types (Hamaker et al., 1995; Larson and Hoffman, 2008). Starch granules in the corn endosperm are surrounded by hydrophobic prolamin proteins, which are slowly degraded (McAllister et al., 1993). Degree of starch access and in vitro ruminal starch digestibility were 32 and $42 \%$ greater, respectively, for the average of FL and OP compared with ISO. Kernel vitreousness, prolamin proteins, degree of starch access, and in vitro ruminal starch digestibility measurements appeared to agree for the comparison of FL and OP, on average, to ISO.

The lactation performance of cows fed the experimental diets is presented in Table 3; these results should be interpreted with caution because of the relatively short duration of the experimental periods. Dry matter intake and milk yield averaged 25.6 and $45.2 \mathrm{~kg} / \mathrm{d}$, re- 
Table 3. Effect of corn endosperm type on least squares means for DMI, milk production, and feed efficiency $^{1}$

\begin{tabular}{|c|c|c|c|c|c|c|}
\hline \multirow[b]{2}{*}{ Item } & \multirow[b]{2}{*}{ ISO } & \multirow[b]{2}{*}{ FL } & \multirow[b]{2}{*}{$\mathrm{OP}$} & \multirow[b]{2}{*}{ SEM } & \multicolumn{2}{|c|}{$(P<)$} \\
\hline & & & & & $\begin{array}{l}\text { ISO vs. } \\
\text { FL, OP }\end{array}$ & FL vs. OP \\
\hline DMI, kg/d & 26.4 & 25.3 & 25.2 & 0.9 & \multicolumn{2}{|c|}{$\mathrm{NS}^{2}$} \\
\hline Milk yield, $\mathrm{kg} / \mathrm{d}$ & 44.0 & 45.1 & 46.4 & 2.5 & \multicolumn{2}{|c|}{ NS } \\
\hline $4 \% \mathrm{FCM}, \mathrm{kg} / \mathrm{d}$ & 40.1 & 41.0 & 42.1 & 2.5 & \multicolumn{2}{|c|}{ NS } \\
\hline Milk fat, $\%$ & 3.38 & 3.42 & 3.36 & 0.14 & \multicolumn{2}{|c|}{ NS } \\
\hline Milk fat, $\mathrm{kg} / \mathrm{d}$ & 1.50 & 1.53 & 1.57 & 0.11 & \multicolumn{2}{|c|}{ NS } \\
\hline Milk protein, $\%$ & 2.63 & 2.77 & 2.68 & 0.03 & 0.01 & 0.09 \\
\hline Milk protein, $\mathrm{kg} / \mathrm{d}$ & 1.16 & 1.23 & 1.24 & 0.07 & \multirow{2}{*}{\multicolumn{2}{|c|}{ NS }} \\
\hline MUN, mg/dL & 18.1 & 18.3 & 17.3 & 0.8 & & \\
\hline \multicolumn{7}{|l|}{ Feed efficiency } \\
\hline $\mathrm{kg}$ of milk $/ \mathrm{kg}$ of DMI & 1.69 & 1.76 & 1.85 & 0.14 & \multicolumn{2}{|c|}{ NS } \\
\hline
\end{tabular}

spectively, for the trial and were unaffected $(P>0.10)$ by treatment. Milk protein percentage was greater $(P$ $<0.01$ ) for cows fed FL and OP than for cows fed ISO, and tended to be greater $(P<0.09)$ for $\mathrm{FL}$ than for OP. Milk protein yield, however, was unaffected $(P>$ $0.10)$ by treatment. The relatively low milk protein and high MUN concentrations that were observed across treatments were likely related to relatively high alfalfa silage and $\mathrm{CP}$ contents and low starch content of the experimental diets (refer to Table 1; NRC, 2001). Furthermore, the relatively low milk percentages across treatments may have been related to the lack of diet formulation for RUP and amino acids (NRC, 2001). Greater milk protein percentage for cows fed FL and OP compared with ISO could have resulted from greater ruminal starch digestibility increasing microbial protein production (NRC, 2001).

Ruminal fermentation parameters of cows fed the experimental diets are presented in Table 4 . Ruminal $\mathrm{pH}$ and acetate molar percentage were lower $(P<0.01)$, propionate molar percentage was greater $(P<0.01)$, and acetate:propionate ratio was lower $(P<0.01)$ for cows fed FL and OP compared with cows fed ISO. Taylor and Allen (2005b) reported similar effects of a floury endosperm type on ruminal $\mathrm{pH}$ and acetate:propionate ratio when fed to lactating dairy cows. Molar percentage of ruminal butyrate was greater $(P<0.05)$ for cows fed FL and OP compared with cows fed ISO, and tended to be greater $(P<0.07)$ for FL than for OP. The concentration of ruminal ammonia nitrogen tended to be lower $(P<0.10)$ for cows fed FL and OP than for cows fed ISO. Hour of sampling relative to feeding affected $(P<0.001)$ ruminal $\mathrm{pH}$, VFA, and ammonia nitrogen, but there were no hour $\times$ treatment interactions $(P>0.10)$. Ammonia nitrogen concentrations in rumen samples obtained $4 \mathrm{~h}$ after the morning feeding, however, were affected $(P<0.04)$ by treatment (ISO $=15.6, \mathrm{FL}=9.7$, and $\mathrm{OP}=11.7 \mathrm{mg} / \mathrm{dL})$. Ruminal fermentation parameters were indicative of greater ruminal starch digestibility (Allen, 1997) for FL and OP.

Results for ruminal in situ DM and starch disappearance from Dacron bags for the experimental corns are presented in Table 5. Zero-hour washout losses of DM and starch from the bags were 8 to 9 percentage units greater $(P<0.01)$ for FL and OP, on average, than for ISO; differences were most likely related to the reduced particle size for FL and OP because of the loss of fine particles through bag pores. Washout loss of starch was greater $(P<0.001)$ for FL than for OP even though the washout loss of DM was similar for these 2 types of corn; we have no explanation for this observation. Dry matter and starch disappearances after 8-h ruminal incubations were 24 and 32 percentage units greater $(P$ $<0.001$ ), respectively, for the average of FL and OP compared with ISO. Corresponding ruminal DM and starch disappearances were 18 to 20 percentage units greater after 16 -h than after 8-h incubations. After 16-h ruminal incubations, disappearances of DM and starch were, on average, 20 and 28 percentage units greater $(P<0.001)$, respectively, for FL and OP than for ISO. Differences $(P<0.05)$ between FL and OP for 16-h DM and 8-h starch disappearances were minor (approximately 6 percentage units). These observations were similar to those of Taylor and Allen (2005a), who reported greater ruminal starch digestibility using ruminally and duodenally cannulated lactating dairy cows for floury than for vitreous corn.

Total-tract apparent nutrient digestibilities in cows fed the experimental diets are presented in Table 6 . Starch digestibility was, on average, 6.3 percentage 
Table 4. Effect of corn endosperm type on ruminal pH, VFA molar percentages, and ammonia nitrogen least squares means for samples obtained immediately before the morning feeding and then at $2,4,8$, and $16 \mathrm{~h}$ postfeeding $^{1}$

\begin{tabular}{|c|c|c|c|c|c|c|}
\hline \multirow[b]{2}{*}{ Item } & \multirow[b]{2}{*}{ ISO } & \multirow[b]{2}{*}{ FL } & \multirow[b]{2}{*}{$\mathrm{OP}$} & \multirow[b]{2}{*}{ SEM } & \multicolumn{2}{|c|}{$(P<)$} \\
\hline & & & & & $\begin{array}{l}\text { ISO vs. } \\
\text { FL, OP }\end{array}$ & FL vs. OP \\
\hline $\mathrm{pH}^{2}$ & 6.62 & 6.46 & 6.53 & 0.05 & 0.01 & $\mathrm{NS}^{3}$ \\
\hline Total VFA, ${ }^{2} \mathrm{~m} M$ & 87.8 & 88.8 & 90.7 & 4.2 & NS & NS \\
\hline \multicolumn{7}{|l|}{ VFA, ${ }^{2}$ molar $\%$} \\
\hline Acetate & 64.5 & 62.3 & 63.1 & 0.6 & 0.01 & NS \\
\hline Propionate & 18.4 & 19.6 & 19.6 & 0.4 & 0.01 & NS \\
\hline Butyrate & 11.9 & 13.1 & 12.3 & 0.4 & 0.05 & 0.07 \\
\hline Others $^{4}$ & 5.2 & $\begin{array}{r}10.1 \\
5.1\end{array}$ & 5.1 & 0.2 & NS & NS \\
\hline Acetate:propionate ${ }^{2}$ & 3.51 & 3.21 & 3.30 & 0.08 & 0.01 & NS \\
\hline Ammonia nitrogen,${ }^{5} \mathrm{mg} / \mathrm{dL}$ & 13.6 & 11.1 & 12.5 & 1.2 & 0.10 & NS \\
\hline \multirow{2}{*}{\multicolumn{7}{|c|}{$\begin{array}{l}{ }^{1} \text { Treatments were dry rolled shelled corn from W64A } \times \text { OH43 }(\mathrm{ISO}), \mathrm{W} 64 \mathrm{~A} \times \mathrm{OH} 43 \text { fl2/fl2 }(\mathrm{FL}) \text {, and W64A } \\
\times \text { OH43 o2/o2 }(\mathrm{OP}) \text { varieties fed in TMR. }\end{array}$}} \\
\hline & & & & & & \\
\hline \multicolumn{7}{|c|}{${ }^{2}$ Hour effect $(P<0.001)$ but no $(P>0.10)$ hour $\times$ treatment interaction. } \\
\hline \multicolumn{7}{|c|}{${ }^{3}$ Not significant $(P>0.10)$} \\
\hline \multicolumn{7}{|c|}{${ }^{4}$ Iso-butyrate, 2-methyl butyrate, iso-valerate, and valerate. } \\
\hline \multicolumn{7}{|c|}{$\begin{array}{l}{ }^{5} \text { Hour effect }(P<0.001) \text {, no }(P>0.10) \text { hour } \times \text { treatment interaction, and effect of treatment }(P<0.04) \text { at } \\
4 \text {-h slice }(\mathrm{ISO}=15.6, \mathrm{FL}=9.7 \text {, and } \mathrm{OP}=11.7 \mathrm{mg} / \mathrm{dL}) .\end{array}$} \\
\hline
\end{tabular}

units greater $(P<0.001)$ for cows fed diets containing FL and OP than for cows fed ISO. Observed in vivo starch digestibility differences coincide with observed differences between the FL and OP versus ISO for vitreousness, prolamin protein content, degree of starch access, in vitro ruminal starch digestibility, and ruminal in situ DM and starch disappearances. The magnitude of the total-tract starch digestibility differences for cows fed diets containing ISO versus FL or OP was likely moderated by postruminal compensatory starch digestion (Taylor and Allen, 2005a). Taylor and Allen (2005a) reported ruminal and total-tract starch digestibilities to be 16 and 5 percentage units greater, respectively, for cows fed diets containing floury com- pared with vitreous corn. Differences in laboratory and in situ measurements defining starch digestibility were small between FL and OP; likewise, no differences $(P>$ $0.10)$ in total-tract nutrient digestibilities for cows fed diets containing these types of corn were observed. Digestibility of NDF was 5.8 percentage units lower $(P<$ 0.001 ), on average, for cows fed diets containing FL and OP than for cows fed ISO. The reduction in total-tract NDF digestibility may have been related to greater ruminal starch digestibility for FL and OP influencing ruminal $\mathrm{pH}$ and VFA (Allen, 1997). A reduction in hindgut NDF digestion (Firkins, 1997) could also partially explain the reduced total-tract NDF digestibility observed in our study, but we collected no data

Table 5. Effect of corn endosperm type on least squares means for ruminal in situ corn DM and starch disappearance from Dacron bags ${ }^{1}$

\begin{tabular}{lllllll}
\hline & & & & & \multicolumn{2}{c}{$(P<)$} \\
\cline { 5 - 7 } & & & & & ISO vs. & \\
Item & ISO & FL & OP & SEM & FL, OP & FL vs. OP \\
\hline DM disappearance, \% & & & & & & \\
0-h & 17.1 & 24.3 & 24.9 & 2.4 & 0.01 & NS $^{2}$ \\
8-h & 38.7 & 60.7 & 64.4 & 2.4 & 0.001 & NS \\
16-h & 59.6 & 75.8 & 82.2 & 2.4 & 0.001 & 0.05 \\
Starch disappearance, \% & 9.5 & 24.9 & 11.8 & 2.9 & 0.01 & 0.001 \\
0-h & 34.7 & 69.6 & 63.3 & 2.9 & 0.001 & 0.05 \\
8-h & 57.3 & 85.7 & 85.2 & 2.9 & 0.001 & NS \\
\hline
\end{tabular}

${ }^{1}$ Treatments were dry rolled shelled corn from W64A $\times$ OH43 (ISO), W64A $\times$ OH43 fl2/fl2 (FL), and W64A $\times$ OH43 o2/o2 (OP) varieties fed in TMR. Added to the Dacron bags for in situ disappearance measurements were the ISO, FL, and OP corn as fed without further processing.

${ }^{2}$ Not significant $(P>0.10)$. 
Table 6. Effect of corn endosperm type on least squares means for total tract apparent nutrient digestibilities ${ }^{1,2}$

\begin{tabular}{|c|c|c|c|c|c|c|}
\hline \multirow[b]{2}{*}{ Item } & \multirow[b]{2}{*}{ ISO } & \multirow[b]{2}{*}{ FL } & \multirow[b]{2}{*}{$\mathrm{OP}$} & \multirow[b]{2}{*}{ SEM } & \multicolumn{2}{|c|}{$(P<)$} \\
\hline & & & & & ISO vs. FL, OP & FL vs. OP \\
\hline DM & 73.1 & 73.6 & 73.4 & 0.6 & $\mathrm{NS}^{3}$ & NS \\
\hline OM & 73.6 & 75.3 & 75.1 & 0.8 & 0.06 & NS \\
\hline $\mathrm{CP}$ & 74.6 & 75.1 & 74.6 & 0.6 & NS & NS \\
\hline NDF & 60.3 & 55.1 & 54.0 & 1.4 & 0.001 & NS \\
\hline Starch & 89.6 & 95.1 & 96.6 & 1.5 & 0.001 & NS \\
\hline
\end{tabular}

${ }^{1}$ Treatments were dry rolled shelled corn from W64A $\times$ OH43 (ISO), W64A $\times$ OH43 fl2/fl2 (FL), and W64A $\times$ OH43 o2/o2 (OP) varieties fed in TMR.

${ }^{2}$ Determined using 120-h indigestible NDF as an internal marker.

${ }^{3}$ Not significant $(P>0.10)$.

to evaluate this premise. The potential for a negative associative effect of greater starch digestibility on NDF digestibility warrants further study in dairy cows fed corn of varying endosperm composition. Because treatment effects on starch and NDF digestibilities were opposing and apparent CP digestibility was unaffected $(P>0.10)$, total-tract $\mathrm{DM}$ and $\mathrm{OM}$ digestibilities were largely unaffected by treatment except for OM digestibility, which tended to be greater $(P<0.0 .6)$ by 1.6 percentage units for FL and OP compared with ISO.

\section{CONCLUSIONS}

In agreement with laboratory and in situ measurements, total-tract starch digestibility was greater for diets fed to lactating dairy cows that contained floury and opaque corns compared with a diet that contained vitreous corn. In contrast, apparent total-tract NDF digestibility was lower for diets containing the floury and opaque corns. Type of corn endosperm influenced starch and NDF digestibility in lactating dairy cows. The potential for a negative associative effect of greater starch digestibility on NDF digestibility warrants further study in dairy cows fed corn of varying endosperm composition.

\section{ACKNOWLEDGMENTS}

The authors appreciate the following contributions: Darwin Frye and staff at the UW-Madison Agricultural Research Station (Arlington, WI) for production and harvest of the experimental corn varieties; Jim Albertson and staff at Wisconsin Foundation Seeds (Arlington, WI) for drying, storage, and processing of the experimental corn varieties; Jerry Guenther and staff at the UW Madison Dairy Cattle Center (Madison, WI) for animal care.

\section{REFERENCES}

Allen, M. S. 1997. Relationship between fermentation acid production in the rumen and the requirement for physically effective fiber. J. Dairy Sci. 80:1447-1462.

Allen, M. S., R. A. Longuski, and Y. Ying. 2008. Endosperm type of dry ground corn affects ruminal and total tract digestion of starch in lactating dairy cows. J. Dairy Sci. 91(E-Suppl. 1):529. (Abstr.)

AOAC. 1995. Official Methods of Analysis. 16th ed. AOAC. Arlington, VA.

Bal, M. A., R. D. Shaver, A. G. Jirovec, K. J. Shinners, and J. G. Coors. 2000. Crop processing and chop length of corn silage: Effects on intake, digestion, and milk production by dairy cows. J. Dairy Sci. 83:1264-1273.

Blasel, H. M., P. C. Hoffman, and R. D. Shaver. 2006. Degree of starch access: An enzymatic method to determine starch degradation potential of corn grain and corn silage. Anim. Feed Sci. Technol. 128:96-107.

Cherney, D. J. R., J. A. Patterson, and R. P. Lemenager. 1990. Influence of in situ bag rinsing technique on determination of dry matter disappearance. J. Dairy Sci. 73:391-397.

Correa, C. E. S., R. D. Shaver, M. N. Pereira, J. G. Lauer, and K. Kohn. 2002. Relationship between corn vitreousness and ruminal in situ starch degradability. J. Dairy Sci. 85:3008-3012.

Ehrman, T. 1996. Determination of starch in biomass samples by chemical solubilization and enzymatic digestion (LAP-016). US. Department of Energy, National Bioenergy Center, Washington, DC

Firkins, J. L. 1997. Effects of feeding nonforage fiber sources on site of fiber digestion. J. Dairy Sci. 80:1426-1437.

Firkins, J. L., M. L. Eastridge, N. R. St-Pierre, and S. M. Noftsger. 2001. Effects of grain variability and processing on starch utilization by lactating dairy cattle. J. Anim. Sci. 79(E Suppl.):E218-E238.

Hamaker, B. R., A. A. Mohamed, J. E. Habben, C. P. Huang, and B. A. Larkins. 1995. Efficient procedure for extracting maize and sorghum kernel proteins reveals higher prolamin contents than the conventional method. Cereal Chem. 72:583-588.

Knowlton, K. F., B. P. Glenn, and R. A. Erdman. 1998. Performance, ruminal fermentation, and site of starch digestion in early lactation cows fed corn grain harvested and processed differently. J. Dairy Sci. 81:1972-1984.

Larson, J., and P. C. Hoffman. 2008. Technical note: A method to quantify prolamin proteins in corn that are negatively related to starch digestibility in ruminants. J. Dairy Sci. 91:4834-4839.

McAllister, T. A., R. C. Phillippe, L. M. Rode, and K. J. Cheng. 1993. Effect of the protein matrix on the digestion of cereal grains by ruminal microorganisms. J. Anim. Sci. 71:205-212.

NRC. 2001. Nutrient Requirements of Dairy Cattle. 7th rev. ed. Nat. Acad. Press, Washington, DC. 
Ngonyamo-Majee, D., R. D. Shaver, J. G. Coors, D. Sapienza, C. E. S. Correa, J. G. Lauer, and P. Berzaghi. 2008a. Relationships between kernel vitreousness and dry matter degradability for diverse corn germplasm. I. Development of near-infrared reflectance spectroscopy calibrations. Anim. Feed Sci. Technol. 142:247-258.

Ngonyamo-Majee, D., R. D. Shaver, J. G. Coors, D. Sapienza, and J. G. Lauer. 2008b. Relationships between kernel vitreousness and dry matter degradability for diverse corn germplasm. II. Ruminal and post-ruminal degradabilities. Anim. Feed Sci. Technol. $142: 259-274$

Philippeau, C., and B. Michalet-Doreau. 1997. Influence of genotype and stage of maturity of maize on rate of ruminal starch degradation. Anim. Feed Sci. Technol. 68:25-35.
SAS Institute. 2004. SAS/STAT 9.1 User's Guide. Version 9.1 ed. SAS Institute Inc., Cary, NC.

Taylor, C. C., and M. S. Allen. 2005a. Corn grain endosperm type and brown midrib 3 corn silage: Site of digestion and ruminal digestion kinetics in lactating cows. J. Dairy Sci. 88:1413-1424.

Taylor, C. C., and M. S. Allen. 2005b. Corn grain endosperm type and brown midrib 3 corn silage: Feeding behavior and milk yield of lactating cows. J. Dairy Sci. 88:1425-1433.

Van Soest, P. J., J. B. Robertson, and B. A. Lewis. 1991. Methods for dietary fiber, neutral detergent fiber, and nonstarch polysaccharides in relation to animal nutrition. J. Dairy Sci. 74:3583-3597.

Waldo, D. R., L. W. Smith, E. L. Cox, B. T. Weinland, and H. L. Lucas. 1971. Logarithmic normal distribution for description of sieved forage materials. J. Dairy Sci. 54:1465-1469. 